\title{
Sward structure and nutritive value of tanzania guineagrass subjected to rotational stocking managements ${ }^{1}$
}

\section{Gelson dos Santos Difante ${ }^{2^{*}}$, Domicio do Nascimento Júnior ${ }^{3}$, Valéria Pacheco Batista Euclides ${ }^{4}$, Sila Carneiro da Silva ${ }^{5}$, Rodrigo Amorim Barbosa ${ }^{4}$, Wellington Velásquez Gonçalves ${ }^{6}$}

\footnotetext{
${ }^{1}$ Pesquisa financiada pela Fundect e pelo CNPq.

2 Programa de Pós-graduação em Zootecnia, UFV. Bolsista CNPq.

${ }^{3}$ Departamento de Zootecnia, UFV. Bolsista do CNPq.

${ }^{4}$ Embrapa Gado de Corte. Bolsista do CNPq.

${ }^{5}$ Departamento de Zootecnia, USP/ESALQ. Bolsista do CNPq

${ }^{6}$ Graduação em Zootecnia - UCDB. Bolsista do CNPq.
}

\begin{abstract}
The objective of this work was to evaluate the sward structure and nutritive value of Panicum maximum Jacq. cv. Tanzânia subjected to rotational stocking managements characterised by a common pre-grazing condition of $95 \%$ canopy light interception (LI) and two post-grazing residues, 25 and $50 \mathrm{~cm}$. Treatments (95/25, 95/50 - LI/residue) were assigned to experimental units (groups of six $2500 \mathrm{~m}^{2}$ paddocks per treatment) according to a complete randomised block design, with two replications. The variables measured corresponded to: canopy light interception, pre and post-grazing sward height, herbage mass and pre and post-grazing morphological composition, herbage bulk density, herbage accumulation and nutritive value (including to IVOMD) of the morphological components. Pre-grazing herbage mass did not differ between residues, although the herbage accumulation rate was higher for the 50 than the $25 \mathrm{~cm}(164.9$ and $90.6 \mathrm{~kg} / \mathrm{ha}$.day DM, respectively). Post-grazing herbage mass values were higher for the $50 \mathrm{~cm}$ residue and were characterised by a higher proportion of leaf blade in relation to the $25 \mathrm{~cm}$ treatment, which presented a higher proportion of dead material. On average, the contents of crude protein (CP), neutral detergent fibre (NDF) and lignin in acid detergent (LAD) as well as the values of the "in vitro" organic matter digestibility (IVOMD) were similar for both treatments. Crude protein and IVOMD decreased and NDF and LAD increased from top to the bottom of the sward, indicating grazing intensity as an important variable for promoting adjustments in the grazing efficiency and nutritive value of the consumed herbage by the grazing animals.
\end{abstract}

Key Words: grazing management, herbage accumulation, Panicum maximum, post-grazing height

\section{Estrutura do pasto e valor nutritivo do capim-tanzânia submetido a estratégias de pastejo rotativo}

RESUMO - Este trabalho foi realizado com o objetivo de avaliar a estrutura e o valor nutritivo de pastos de Panicum maximum Jacq. cv. Tanzânia sob regime de desfolhação intermitente submetido a duas intensidades de desfolhação e a duas alturas de resíduo (25 e 50 cm) associadas à condição pré-pastejo definida por 95\% de interceptação da luz incidente (IL) pelo dossel forrageiro. O experimento foi conduzido em delineamento de blocos completos casualizados, com duas repetições. Foram avaliadas as condições de interceptação de luz incidente, as alturas pré e pós-pastejo, a massa de forragem pré e pós-pastejo e seus componentes morfológicos, a taxa de acúmulo, a densidade volumétrica da forragem e o valor nutritivo dos componentes morfológicos da forragem disponível. A massa de forragem no pré-pastejo foi semelhante entre as intensidades de desfolhação, apesar de a taxa de acúmulo nos pastos com $50 \mathrm{~cm}$ de resíduo ter sido maior (164,9 kg/ha.dia de MS) que a daqueles com $25 \mathrm{~cm}$ de resíduo (90,6 kg/ha.dia de MS). A massa de forragem no pós-pastejo foi maior nos pastos rebaixados para resíduo de $50 \mathrm{~cm}$ e apresentou maior percentual de lâminas foliares na sua composição morfológica. Os teores de proteína bruta (PB) e a digestibilidade in vitro de matéria orgânica (DIVMO), fibra em detergente neutro (FDN) e lignina em detergente ácido (LDA) foram semelhantes entre as intensidades de desfolhação. Entretanto, à medida que o estrato da vegetação se aproximou do solo, os teores de PB e a DIVMO diminuíram e os teores de fibra em detergente neutro e de lignina em detergente ácido aumentaram. Esses resultados indicam a intensidade de pastejo como variável importante para ajustes na eficiência de pastejo e no valor nutritivo da forragem disponível para animais em pastejo.

Palavras-chave: acúmulo de forragem, altura de resíduo, manejo do pastejo, Panicum maximum 


\section{Introduction}

Tropical forage grasses are characterized by a high potential of herbage accumulation, although the general productivity and efficiency indexes of tropical pastoral systems are relatively low (Nascimento Jr. et al., 2004). In such systems, there is no single solution, and the manipulation of a simple and/or isolated variable does not result in immediate and effective modifications in the overall process and animal production efficiency. This highlights the complexity and the integration between components and processes, and indicates the need for integrating knowledge and information in order to plan efficient grazing management practices (Sbrissia \& Da Silva, 2001).

Recent evidences on the management of tropical grasses have shown that the use of sward target-based grazing management strategies can result in significant increments in use and grazing efficiency. Results for Mombaça (Carnevalli et al., 2006) and Tanzânia (Barbosa et al., 2007) grass subjected to rotational grazing managements characterized by pre-grazing conditions determined by levels of sward canopy light interception during regrowth have demonstrated that there is an overlap between the conditions necessary for the efficient production of herbage mass and those for producing herbage with high nutritive value.

In general, plants and animals respond consistently to variations in sward height, following a similar response pattern of temperate grass species (Da Silva \& Carvalho, 2005). The magnitude and absolute value of these responses can vary according to the morphophysiological characteristics of the plant and animal species involved, but follow similar functional response patterns. This opens a vast new horizon for managing tropical pastures in which the use of sward target-based grazing management practices becomes a reality and allows for generalization across a wide range of environments, respecting the rhythm of plant growth and development (Hodgson \& Da Silva, 2002; Da Silva, 2004).

The objective of this experiment was to evaluate the sward structure and the nutritive value of the herbage produced on Panicum maximum Jacq. cv. Tanzânia subjected to rotational stocking managements characterized by a common pre-grazing (95\% LI) and two post-grazing (post-grazing heights of 25 and $50 \mathrm{~cm}$ ) conditions.

\section{Material and Methods}

The experiment was carried out at Embrapa Gado de Corte, Campo Grande, MS, Brazil (20 $27^{\circ}$ S, 54 $4^{\circ} 37^{\prime} \mathrm{W}$ and 530 m a.s.l.) on a Panicum maximum Jacq. cv. Tanzânia pasture established in January 1995 and used for grazing since August 1995. The use of the area for this experiment started in 9/29/2004 and finished in 5/18/2005, totaling 232 days. During the first 75 days (9/29 to 12/12/2004) the area was prepared for the experiment, and activities involved collecting soil samples for chemical analysis, weed control, renovation and adjustments on fences and water lines and troughs, application of limestone and fertilizers, and mowing. The next 157 days (12/13/2004 to 5/18/2005) corresponded to the experimental period itself, during which measurements were made and data were collected.

Climate in Campo Grande corresponds to the humid tropical type, sub-type Aw (Köppen classification), with a dry season during autumn and winter. Rainfall data were recorded on the experimental site and data for relative air humidity and temperatures recorded in a meteorological station located at approximately $800 \mathrm{~m}$ away (Figure 1).

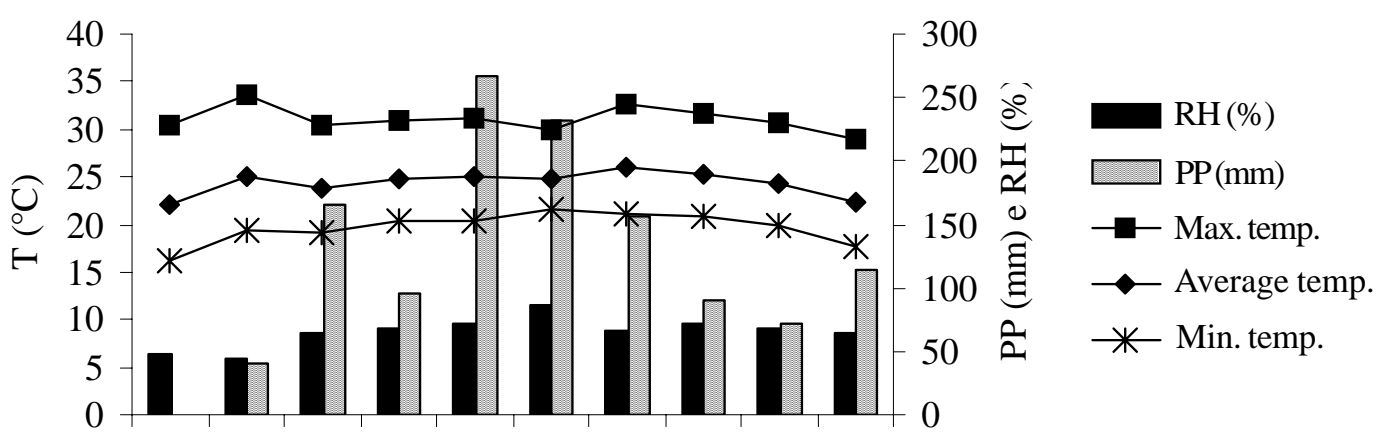

Aug. Sep. Oct. Nov. Dec. Jan. Feb. Mar. Apr. May

Figure 1 - Rainfall (PP, mm), relative air humidity (RH, \%), maximum, average and minimum temperatures $\left({ }^{\circ} \mathrm{C}\right)$ during the experimental period. 
The water soil balance (surplus and deficit) was calculated using the monthly rainfall and average temperature data throughout the experimental period (Figure 2).

The soil in the experimental area is a Rhodic Ferralsol (FAO, 2006), and the fertility was monitored aiming at maintaining levels from 50 to $70 \%$ of base saturation, 8 to $12 \mathrm{mg} / \mathrm{dm}^{3}$ of phosphorus (P - Mehlich) and 80 to $100 \mathrm{mg} / \mathrm{dm}^{3}$ of potassium. Soil samples were collected on Sept. 30 and Oct. 01, 2004, being 12 from the $0-10 \mathrm{~cm}$ depth, 12 from the $0-20 \mathrm{~cm}$ depth and 12 from the $20-40 \mathrm{~cm}$ depth, a total of 36 samples from each $2500 \mathrm{~m}^{2}$ paddock (Table 1 ).

Based on the results above, paddocks received $1,000 \mathrm{~kg} / \mathrm{ha}$ of limestone, $800 \mathrm{~kg} / \mathrm{ha}$ of gypsum and $500 \mathrm{~kg} /$ ha of a 0:20:20 fertilizer compound (N:P:K). Paddocks also received $150 \mathrm{~kg} / \mathrm{ha}$ of $\mathrm{N}$ (urea), applied in installments. Since the interval between successive grazing varied with treatments and season of the year, the quantities and dates of $\mathrm{N}$ fertilizer application also varied, but ensuring that the same amount of fertilizer was used for each treatment at the end of the experimental period.

The experimental area was divided up into 3 ha modules, with 12 paddocks each, totaling 9.0 ha. Each module was divided up into two sets of six paddocks $\left(2,500 \mathrm{~m}^{2}\right)$. One of the modules was used as a reserve area, where the animals used for adjustments in stocking rate were kept throughout the experiment. Treatments corresponded to two levels of grazing intensity characterized by post-grazing heights of 25 and $50 \mathrm{~cm}$ associated to a common pre-grazing condition characterized by $95 \% \mathrm{LI}$, and were designated as follows:

95/25 = 95\% LI pre-grazing and $25 \mathrm{~cm}$ post-grazing height

95/50 $=95 \%$ LI pre-grazing and $50 \mathrm{~cm}$ post-grazing height

These were assigned to experimental units (sets of six paddocks) according to a complete randomized block design, with two replicates. The six paddocks per experimental unit allowed that each experimental unit was managed as a self-contained farmet, with animals assigned to them corresponding to the "farmlet herd". A total of 24 paddocks were used for this purpose.

Grazing was carried out using 60 young Nelore bulls (approximately 12 months of age) with average initial body weight of $221 \mathrm{~kg}$. The grazing method used was the rotational stocking, with variable stocking rate and rest

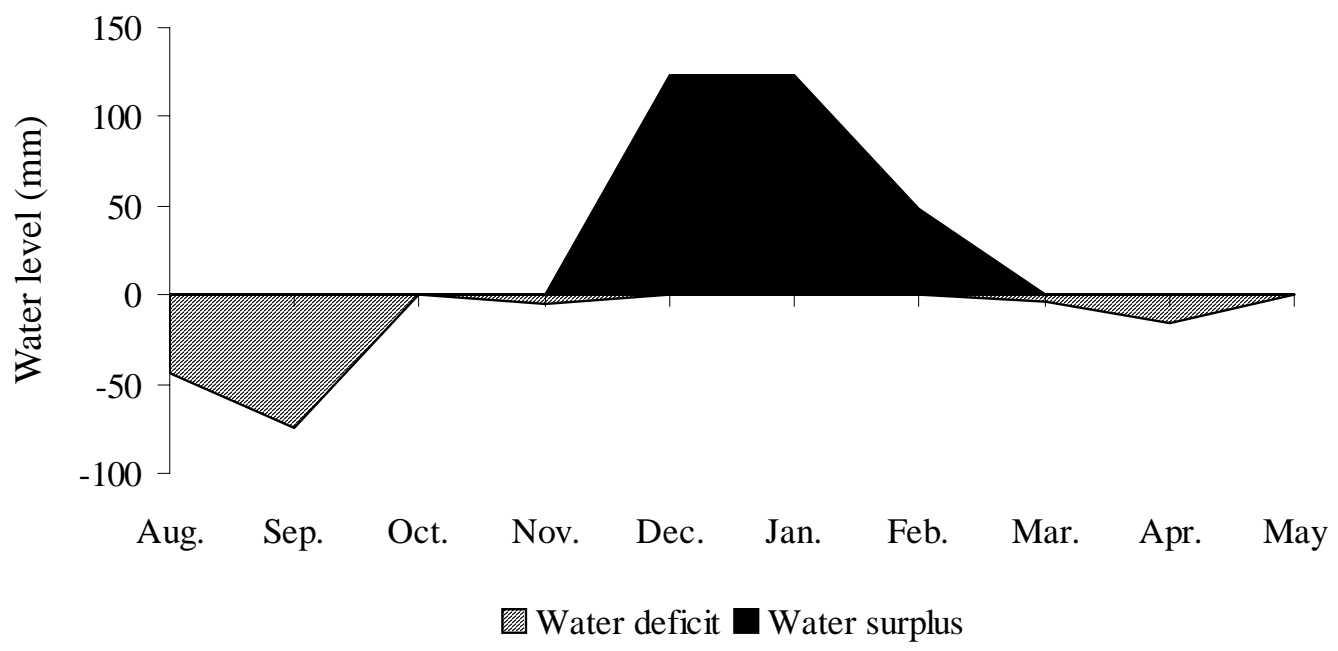

Figure 2 - Water deficit and surplus in the soil during the experimental period.

Table 1 - Chemical characteristics of the soil on the experimental area at the 0-10 cm, 0-20 cm and 20-40 cm depths

\begin{tabular}{|c|c|c|c|c|c|c|c|c|c|c|}
\hline $\begin{array}{l}\text { Depth } \\
\text { cm }\end{array}$ & $\begin{array}{c}\mathrm{P} \\
\mathrm{mg} / \mathrm{dm}^{3}\end{array}$ & $\begin{array}{c}\mathrm{OM} \\
\%\end{array}$ & $\begin{array}{c}\mathrm{pH} \\
\mathrm{CaCl}_{2}\end{array}$ & $\begin{array}{c}\mathrm{K} \\
\mathrm{mg} / \mathrm{dm}^{3}\end{array}$ & $\mathrm{Ca}$ & $\mathrm{Mg}$ & $\begin{array}{c}\mathrm{H}+\mathrm{Al} \\
\mathrm{cmol}_{\mathrm{c}} / \mathrm{dm}^{3}\end{array}$ & S & $\mathrm{T}$ & $\begin{array}{l}\mathrm{V} \\
\%\end{array}$ \\
\hline $0-10$ & 3.74 & 5.00 & 5.31 & 162.48 & 2.58 & 1.85 & 4.50 & 4.84 & 9.09 & 53.34 \\
\hline $20-40$ & 0.78 & 2.99 & 4.70 & 39.40 & 0.78 & 0.48 & 3.27 & 1.36 & 4.88 & 28.02 \\
\hline
\end{tabular}


period determined by the level of sward canopy light interception during regrowth (LI). In November 2004, paddocks started to be grazed and mowed, soon after grazing, in order to ensure that the targets of post-grazing heights had been precisely achieved. Mowing was carried out on a weekly basis on one paddock per module with the objective of ensuring a regrowth gradient between paddocks within modules. This procedure was used until all paddocks of each module had been mowed.

The monitoring of the canopy light interception was made throughout each regrowth cycle using a canopy analyzer AccuPAR Linear PAR/LAI ceptometer, Model PAR -80 (DECAGON Devices). At the beginning of the regrowth period, measurements were made on a weekly basis, starting at the post-grazing condition, but when readings started to get close to $90 \%$, measurements were performed every two to three days until the target of $95 \%$ LI was reached. Readings were performed along three transect lines with six sampling points each, totaling 18 sampling points per paddock. In each point, one reading was performed above the canopy and five at ground level (optical sensor placed at the mid distance between tussocks), totaling 18 readings above the canopy and 90 at the ground level per paddock for each measurement date.

Sward height was measured using a 1 m ruler, with readings performed on eight points randomly chosen along each five transect lines across the paddocks, totaling 40 readings per paddock. At each point, the sward height corresponded to the distance between the ground and plane defined by the curved top leaves around the ruler. Sward height measurements were performed at the same measurement dates and the canopy light interception were made throughout the regrowth period.

Pre-grazing herbage mass was determined by harvesting the herbage within two $1 \mathrm{~m}^{2}$ quadrats on three of the six paddocks of each experimental unit, totaling six quadrats per treatment replication. Quadrats were placed on representative areas of the sward at the time of sampling (visual assessment of herbage mass and height) using two stands $25 \mathrm{~cm}$ of height in order to achieve cutting heights of 25 and $50 \mathrm{~cm}$. In each sampling point (quadrat), herbage was cut considering three strata: (1) above $50 \mathrm{~cm}$ from the ground; (2) between 50 and $25 \mathrm{~cm}$ from the ground; and (3) between $25 \mathrm{~cm}$ and ground level. From these samples, a sub-sample about half-size of the sample was separated, put into paper bags and dried in forced draught oven at $65^{\circ} \mathrm{C}$ until reaching constant weight, which was used to calculate the herbage dry matter content and the samples dry weight. Pre-grazing herbage mass was obtained by adding the sum of the herbage dry weight from the three strata. Another two sub-samples were generated and hand dissected into leaf (leaf blade), stem (stem + leaf sheath) and dead material. Components were dried in forced draught oven, similarly to the herbage mass samples, and dry weights used to calculate the morphological composition of samples expressed as percentage. Post-grazing herbage mass and morphological composition were determined using a procedure similar to that described for pre-grazing herbage mass.

Herbage accumulation (kg DM/ha) for each grazing cycle was calculated as the difference between pre-grazing and previous post-grazing herbage mass for each sampling paddock, and the herbage accumulation rate (kg DM/ha.day) was obtained by dividing the result by the interval between grazing for the specific grazing cycle.

The herbage bulk density (kg DM/ha.cm) was calculated dividing the herbage mass ( $\mathrm{kg} \mathrm{DM} / \mathrm{ha}$ ) on the three sampled strata by the depth $(\mathrm{cm})$ of each stratum. Similar procedure was used to calculate leaf, stem and dead material bulk density.

The dried sub-samples of the morphological components (leaf, stem and dead material) were ground and subjected to estimations of the nutritive value (including IVOMD) using NIRS, according to Merten et al. (1985). The estimated variables were: organic matter content (OM), crude protein (CP), neutral detergent fiber (NDF), "in vitro" organic matter digestibility (IVOMD) and acid detergent lignin (ADL).

The sward descriptive characteristics (light interception and pre and post-grazing heights) are presented using descriptive statistics only. On the other hand, variables related to the sward structural characteristics, herbage nutritive value and herbage accumulation were analyzed using a model in which treatments (post-grazing heights), grazing cycle and their interaction were considered as fixed effects and block considered as random effect. For the stratified herbage mass samples, the same model was used (split-plot arrangement), but the strata effect was added and considered as fixed. The analysis were carried out using the PROC Mixed of SAS $\odot$, and means were calculated using LSMEANS.

\section{Results and Discussion}

Grazing swards down to $25 \mathrm{~cm}$, sward height and light interception showed a minor reduction with successive grazing cycles (Figure 3A). On the other hand, for grazing swards down to $50 \mathrm{~cm}$, values were relatively stable for both sward height and pre-grazing light interception, except for sward height at the last grazing cycle, which showed a minor 
reduction in relation to previous grazing cycles (Figure 3B). In general, targets of post-grazing residue were maintained under control throughout the experimental period, regardless the grazing treatment. Nominal values of post-grazing sward height are shown in Figures 3C and 3D. For both treatments, post-grazing heights were fairly constant and close to the specified targets of 25 and $50 \mathrm{~cm}$, respectively.

However, there was a greater degree of difficulty for grazing paddocks down to $25 \mathrm{~cm}$ in relation to those at $50 \mathrm{~cm}$, consequence of the reluctance of animals to graze the lower stratum of the sward at the end of the occupation period, which had only around $11.5 \%$ of leaf in the remaining herbage mass. On the other hand, grazing on paddocks down to $50 \mathrm{~cm}$ was relatively easy, with surrent post-grazing height values reached at the end of the occupation period slightly lower than the specified target (mean of $47.8 \mathrm{~cm}$ ).

Grazing intervals varied significantly $(\mathrm{P}=0.0547)$ with the post-grazing heights used (Figure 4). Grazing swards down to $50 \mathrm{~cm}$ resulted in shorter grazing intervals than of $25 \mathrm{~cm}$ (average of 33 and 50 days, respectively), which caused a larger number of grazing cycles for the $50 \mathrm{~cm}$ post-grazing height treatment at the end of the experimental period.
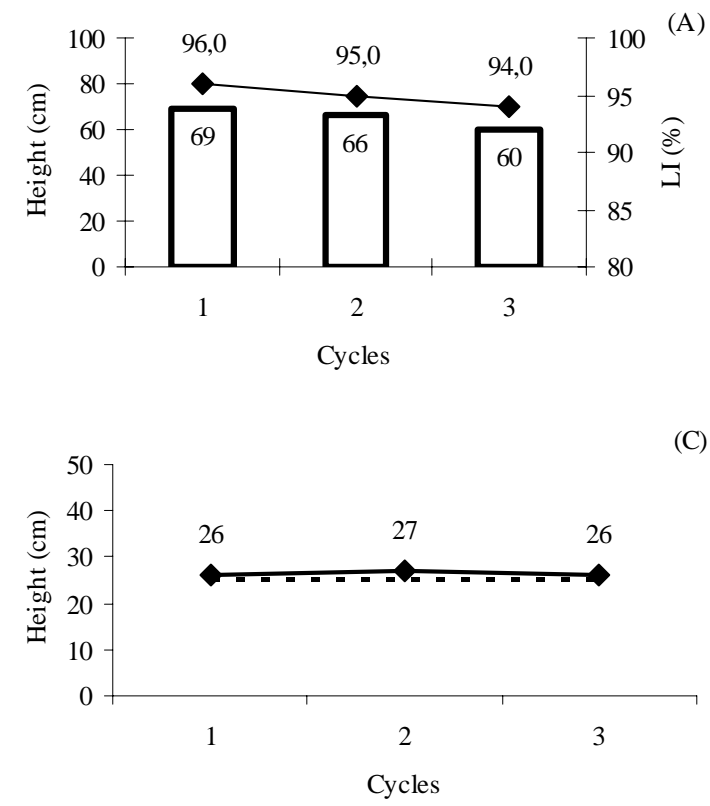

(A)

C)
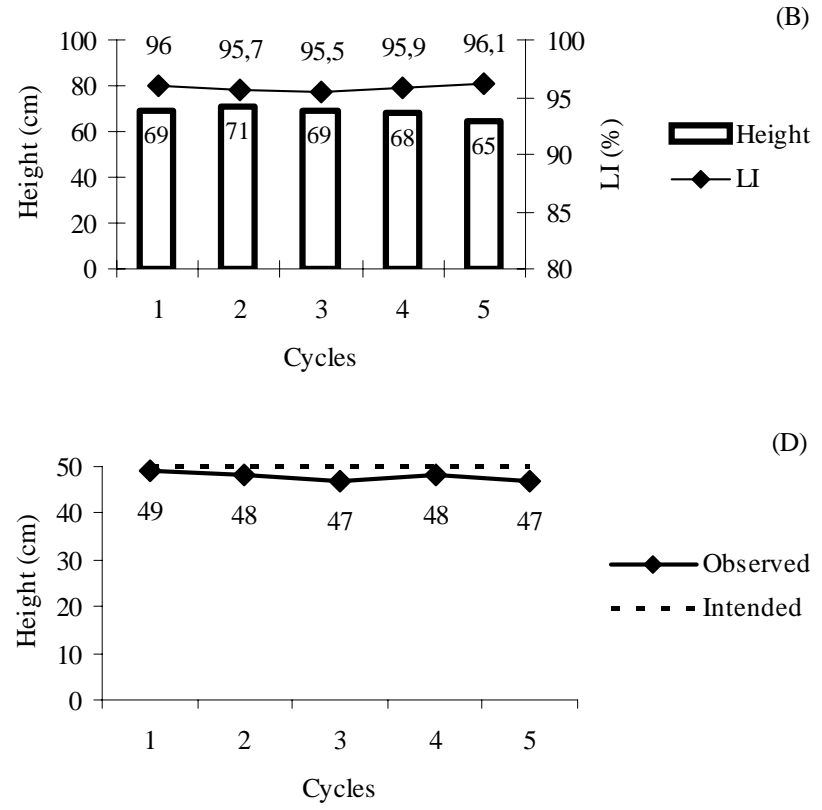

Figure 3 - Pre-grazing sward height (cm) and light interception (\%) for treatments 95/25 (A) and 95/50 (B), and nominal values of postgrazing sward height (cm) for the post-grazing targets of 25 (C) and $50 \mathrm{~cm}(\mathrm{D})$ in Tanzania guineagrass subjected to rotational stocking managements.

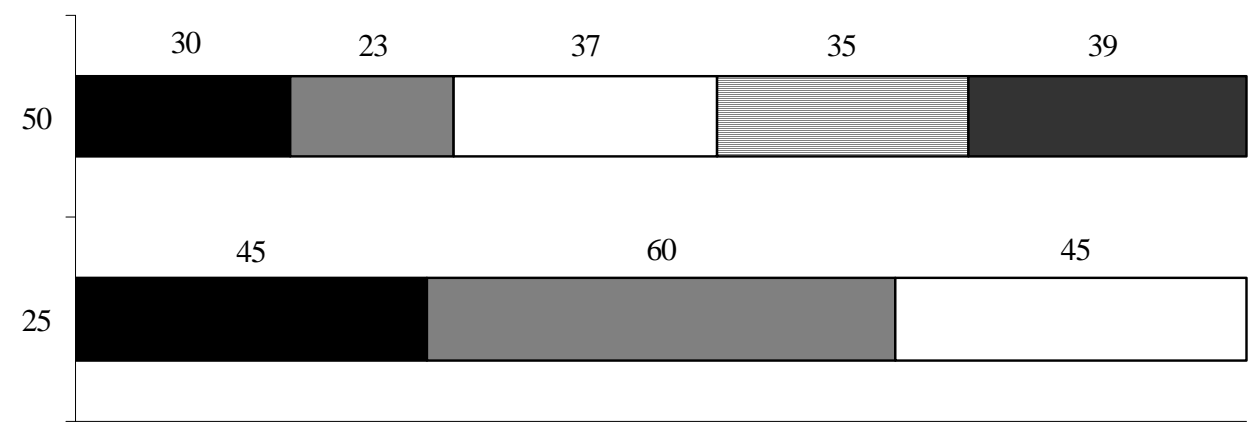

Grazing intervals (days)

Cycle $1 \square$ Cycle $2 \square$ Cycle 3 目Cycle $4 \square$ Cycle 5

Figure 4 - Grazing intervals (days) and grazing cycles (number) for Tanzania guineagrass swards subjected to grazing at 95\% LI down to post-grazing residues of 25 and $50 \mathrm{~cm}$. 
The longer grazing interval for $95 / 25$ was a result of the lower residual LAI under that grazing condition, as reported by Barbosa et al. (2007) for Tanzania guineagrass using an analogous research protocol in relation to the one used in this experiment. The authors reported post-grazing sward light interception levels of 50.2 and $62.3 \%$ for the postgrazing residues of 25 and $50 \mathrm{~cm}$, respectively, and stated that these differences in LI post-grazing were determinant of how fast sward reached the 95\% LI pre-grazing condition for the beginning of the next grazing cycle.

The grazing interval was also affected by rainfall throughout the experimental period (Figures 1 and 2). During December, January and February, when rainfall was concentrated, recorded grazing intervals were short. This finding was also reported by Barbosa et al. (2007), and just reflects the seasonal pattern of tropical and subtropical grasses production (Pedreira \& Mattos, 1981). It is also likely that the longer grazing interval for $95 / 25$ between the first and second grazing periods (60 days) was a consequence of the non application of nitrogen fertilizer at that time of the year. Since the grazing interval between the first and second grazing period for 95/50 was shorter (30 days), this treatment received a nitrogen fertilizer application 21 days before 95/25, which could have favored 95/50 since nitrogen application coincided with a favorable period for pasture growth (high temperature and rainfall).

The pre-grazing herbage mass was not affected by the grazing treatment $(\mathrm{P}=0.0635)$. However, herbage mass varied with grazing cycles within the grazing treatments $(\mathrm{P}=0.0001$ ) (Figure 5A). Grazing swards down to $50 \mathrm{~cm}$ resulted in pre-grazing higher herbage mass during the last grazing cycle, which is a probable consequence of the accumulation of stem material throughout the experimental period (Figure 6). This suggests that the control of the sward structure on swards grazed to $50 \mathrm{~cm}$ was not effective, and this could have potentially negative future implications to herbage accumulation and nutritive value at medium and long terms.

Considering the vertical strata of the sward and their morphological composition, there was no grazing treatment $\times$ vertical strata $(\mathrm{P}=0.0716)$ and grazing cycle $\times$ vertical strata $(\mathrm{P}=0.2251)$ interactions. Variations were only related to sward vertical strata $(\mathrm{P}=0.026)$ (Figure $5 \mathrm{~B})$. Atpre-grazing, the herbage mass was higher in the $0-25 \mathrm{~cm}$ stratum than in the 25-50 and over the $50 \mathrm{~cm}$ strata, with values decreasing as the sward height increased.

The similar values of pre-grazing herbage mass for both grazing treatments in this study may be a consequence of the same pre-grazing LI target used. Regardless the grazing treatment, the two upper strata $(25-50 \mathrm{~cm}$ and over $50 \mathrm{~cm})$, potentially available for grazing, showed lower herbage mass than the lower stratum $(0-25 \mathrm{~cm})$, but their morphological composition was characterized by an high percentage of leaves relative to stems and dead material, a component of high nutritive value (Brâncio et al., 2002) and usually present in high percentage in the herbage selected by the grazing animals during grazing (Brâncio et al., 2003).

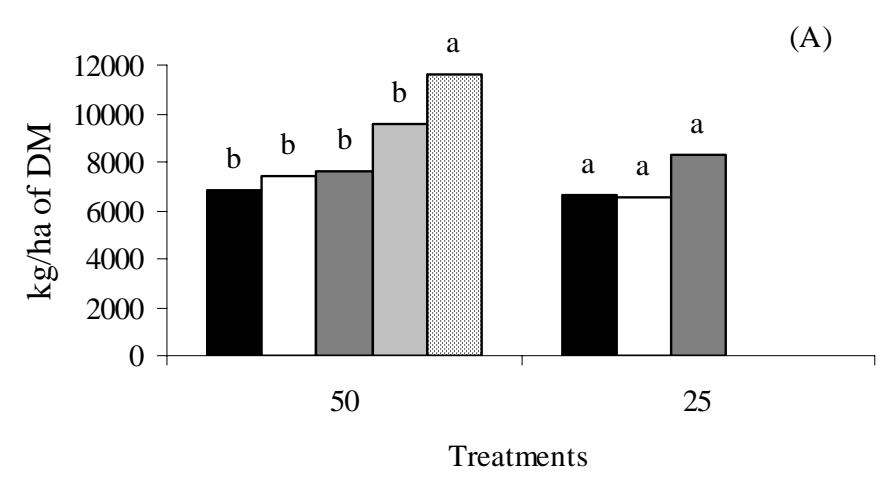

口Cycle 1 Cycle $2 \square$ Cycle 3 Cycle $4 \square$ Cycle 5

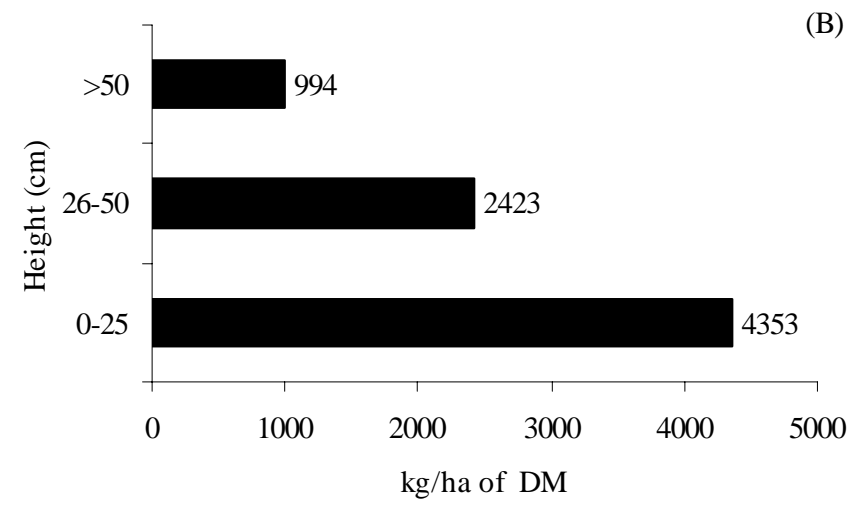

Means, within treatments, followed by the same lower case letter are not different $(\mathrm{P}>0.05)$ - Tukey.

Standard error $(\mathrm{A})=829.21 ;(\mathrm{B})=85.86$

Figure 5 - Pre-grazing herbage mass per grazing cycle (A) and sward stratum (B) (kg/ha of DM) of Tanzania guineagrass subjected to rotational stocking managements. 

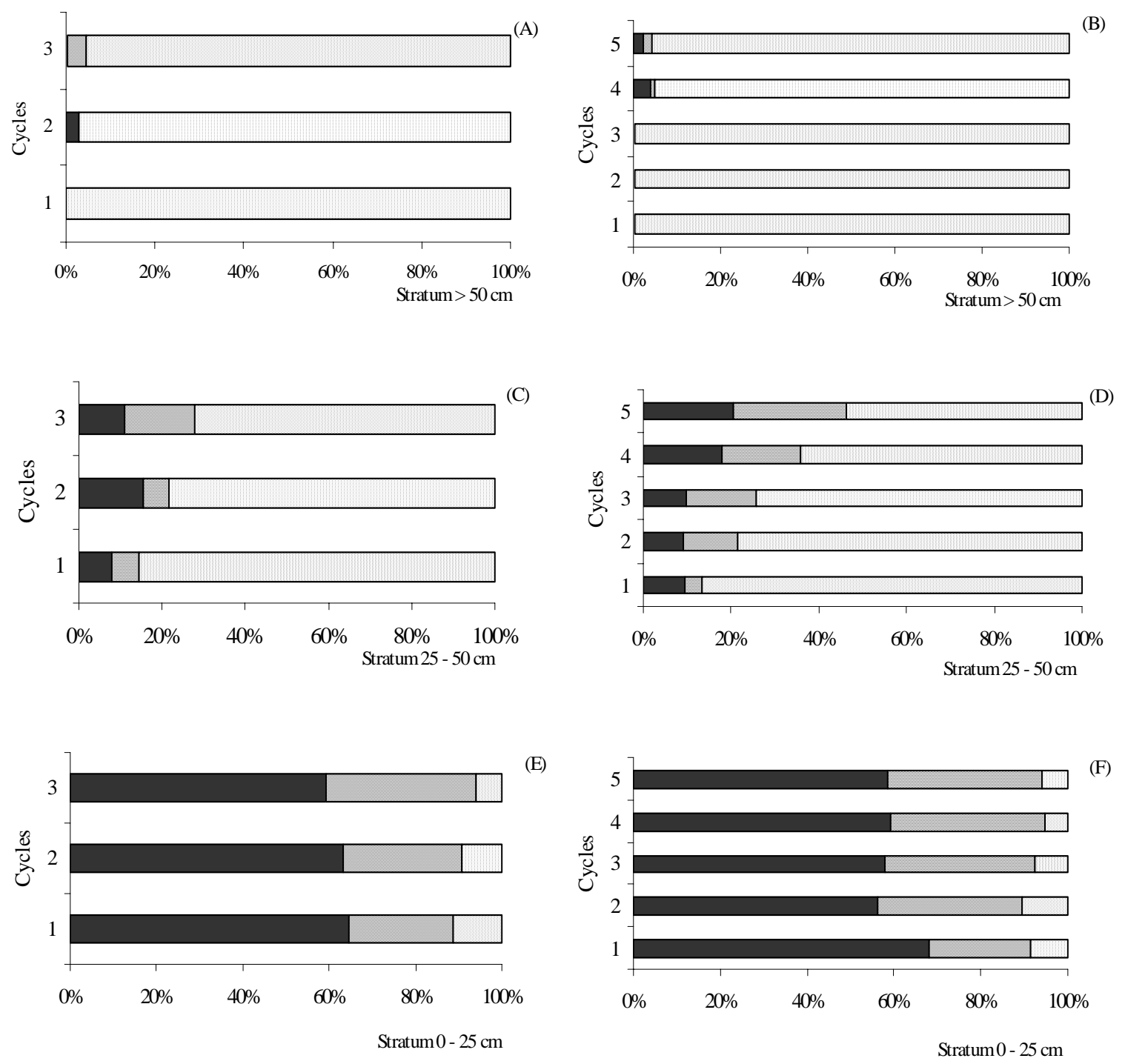

\% Dead material $\square \%$ Stem $\square \%$ Leaf

Figure 6 - Percentage of leaf, stem and dead material in the strata of the pre-grazing herbage mass of Tanzania guineagrass submitted to treatments 95/25(A, C and E) and 95/50 (B, D and F) according to the grazing cycles throughout the experiment.

There was no grazing treatment $x$ vertical strata interaction for the percentage of leaf $(\mathrm{P}=0.6401)$, stem $(\mathrm{P}=0.1509)$ and dead material $(\mathrm{P}=0.8274)$ in the pre-grazing herbage mass. As far as grazing treatments are concerned, there was no difference in the percentage of leaf $(\mathrm{P}=0.0689)$ and dead material ( $\mathrm{P}=0.3366$ ), but the percentage of stem was higher for $95 / 50$ than for $95 / 25(P=0.0108)$ (Table 2$)$.

Morphological composition of the pre-grazing herbage mass varying with the vertical strata of the sward $(\mathrm{P}<0.01)$ (Table 3). The percentage of leaf was low in the $0-25 \mathrm{~cm}$, but increased as the sward height increased moving into the 25-50 and over $50 \mathrm{~cm}$ strata, reaching $97.9 \%$ in this last stratum. The percentage of stem and dead material showed an opposite behavior, with lower values at the upper strata and higher values at the $0-25 \mathrm{~cm}$ stratum.

There was no vertical strata $\times$ grazing cycle within grazing treatments interaction for the percentage of leaf $(P=0.2458)$, stem $(P=0.1593)$ and dead material $(\mathrm{P}=0.4848)$, and neither grazing cycle effect for the percentage of pre-grazing dead material $(\mathrm{P}=0.5618)$. However, the percentage of leaf $(\mathrm{P}=0.058)$ and stem $(\mathrm{P}=0.001)$ varied with the grazing cycle (Figure 6).

The lower stratum of swards $(0-25 \mathrm{~cm})$ showed consistently higher percentage of pre-grazing stem and 
Table 2 - Percentage of leaf, stem and dead material in the pregrazing herbage mass of tanzania guineagrass subjected to rotational stocking managements

\begin{tabular}{lccc}
\hline Treatment & Leaf & Stem & Dead material \\
\hline $95 / 25$ & $61.7 \mathrm{a}(0.17)$ & $13.4 \mathrm{~b}(0.03)$ & $25.0 \mathrm{a}(0.20)$ \\
$95 / 50$ & $59.6 \mathrm{a}(0.14)$ & $15.9 \mathrm{a}(0.27)$ & $24.5 \mathrm{a}(0.17)$
\end{tabular}

Means followed by the same lower case letter in columns are not different $(\mathrm{P}>0.05)$ - Tukey.

Values in parentheses refer to the standard error.

Table 3 - Percentage of leaf, stem and dead material pre-grazing in the vertical strata of Tanzania guineagrass swards subjected to rotational stocking managements

\begin{tabular}{lrrr}
\hline Strata & \multicolumn{1}{c}{ Leaf } & \multicolumn{1}{c}{ Stem } & Dead material \\
\hline $0-25 \mathrm{~cm}$ & $8.2 \mathrm{c}(1.62)$ & $30.5 \mathrm{a}(0.98)$ & $61.3 \mathrm{a}(1.87)$ \\
$25-50 \mathrm{~cm}$ & $75.8 \mathrm{~b}(1.62)$ & $12.3 \mathrm{~b}(0.98)$ & $11.9 \mathrm{~b}(1.87)$ \\
$>50 \mathrm{~cm}$ & $97.9 \mathrm{a}(1.62)$ & $1.1 \mathrm{c}(0.98)$ & $1.0 \mathrm{c}(1.87)$
\end{tabular}

Means followed by the same lower case letter in columns are not different $(\mathrm{P}>0.05)$ - Tukey.

Values in parentheses refer to the standard error.

dead material throughout the experimental period. In the intermediate stratum $(25-50 \mathrm{~cm})$, there was a higher percentage of leaf, but still with significant percentage of stem and dead material, which had their contribution to the increased herbage mass in this stratum as the experiment progressed and grazing cycles evolved. The upper stratum (over $50 \mathrm{~cm}$ ) was comprised almost exclusively by leaf material, with stem and dead material showing a small increase towards the end of the experiment during the last grazing cycles.

In the post-grazing period, the herbage mass varied with grazing treatments $(P=0.0006)$, with grazing at $25 \mathrm{~cm}$ post-grazing residue resulting in lower herbage mass than those at $50 \mathrm{~cm}$ (3810 and $5080 \mathrm{~kg} \mathrm{DM} / \mathrm{ha}$, respectively). When grazing cycles are considered within grazing treatments, a higher herbage mass value was detected at the last grazing cycle for the $95 / 50(\mathrm{P}<0.0001)$. For $95 / 25$, the post-grazing herbage mass did not change with the grazing cycles $(\mathrm{P}>0.05)$.

There was no difference between treatments for the percentage of stem $(\mathrm{P}=0.8677)$. However, higher percentage of leaf was recorded for $95 / 50(\mathrm{P}=0.0463)$ and higher percentage of dead material for $95 / 25(\mathrm{P}=0.0375)$ (Table 4).

Swards grazed at $50 \mathrm{~cm}$ post-grazing residue showed a decrease in the percentage of leaf and an increase in the percentage of stem with successive grazing cycles $(\mathrm{P}<0.05)$. On the other hand, in swards grazed at $25 \mathrm{~cm}$ post-grazing residue, there was no variation in the percentage of any of the morphological components
Table 4 - Percentage of leaf, stem and dead material in the postgrazing herbage mass of Tanzania guineagrass swards subjected to rotational stocking managements

\begin{tabular}{lccc}
\hline Treatment & Leaf & Stem & Dead material \\
\hline $95 / 25$ & $11.5 \mathrm{~b}(1.15)$ & $30.0 \mathrm{a}(2.07)$ & $58.6 \mathrm{a}(0.91)$ \\
$95 / 50$ & $32.4 \mathrm{a}(0.99)$ & $29.4 \mathrm{a}(1.77)$ & $38.3 \mathrm{~b}(0.78)$ \\
\hline
\end{tabular}

Means followed by the same lower case letter in columns are not different ( $\mathrm{P}>0.05)$ - Tukey.

Values in parentheses refer to the standard error.

(leaf, stem and dead material) throughout the experimental period. Similar behavior was recorded for the percentage of dead material when grazing was carried out using the post-grazing target of $50 \mathrm{~cm}$ residue. The lower grazing intensity or herbage removal associated with the postgrazing residue of $50 \mathrm{~cm}$ explains the higher percentage of leaves under these circumstances, once practically all morphological components in the strata 0-25 and 25-50 $\mathrm{cm}$ are not removed by the grazing animals, the inverse behavior for the post-grazing height of $25 \mathrm{~cm}$. However, the relatively constant morphological composition of the post-grazing herbage mass of swards grazed at $25 \mathrm{~cm}$ residue indicates a better control of the sward structure when a more severe grazing was used.

The herbage accumulation rates were higher for $95 / 50$ than for $95 / 25$ ( $P=0.0951)$, and did not change with the grazing cycles $(\mathrm{P}=0.6593)$. The average herbage accumulation rates for $95 / 25$ and $95 / 50$ during the experimental period were 90.6 and $164.9 \mathrm{~kg} \mathrm{DM} / \mathrm{ha}$.day. Despite this large difference between the herbage accumulation rates (around $82 \%$ ), there was no difference in the pregrazing herbage mass between treatments, since it was compensated for the shorter grazing intervals for $95 / 50$ in relation to $92 / 25$. The longer grazing intervals for $95 / 25$ allowed swards to accumulate a similar amount of herbage before grazing in relation to that for $95 / 50$, indicating the importance of monitoring and adjusting the grazing frequency as a means of controlling the pre-grazing sward herbage mass.

The herbage bulk density (kg DM/ha.cm) was not affected by either grazing treatment $\times$ vertical strata $(\mathrm{P}=0.0528)$ or vertical strata $\times$ grazing cycle $(\mathrm{P}=0.4698)$ interactions (Table 5). Swards grazed down to the postgrazing residue of $50 \mathrm{~cm}$ had higher herbage bulk density than those grazed at $25 \mathrm{~cm}(\mathrm{P}=0.0407)$, possibly a consequence of the higher percentage of the stem component in the pre-grazing herbage mass (Table 2). Values of herbage bulk density were higher on the lower stratum $(0-25 \mathrm{~cm})$ and decreased towards the top horizon of the sward (25-50 and over $50 \mathrm{~cm})(\mathrm{P}=0.0037)$, with the 
Table 5 - Herbage bulk density (kg/cm.ha) pre-grazing of Tanzania guineagrass subjected to rotational stocking managements according to vertical strata of the sward

\begin{tabular}{lccr}
\hline Strata & \multicolumn{2}{c}{ Treatment } & \multicolumn{1}{c}{ Mean } \\
\cline { 2 - 3 } & $95 / 25$ & $95 / 50$ & \\
\hline $0-25 \mathrm{~cm}$ & 170.9 & 177.4 & $174.1 \mathrm{~A}(3.67)$ \\
$25-50 \mathrm{~cm}$ & 80.6 & 113.3 & $96.9 \mathrm{~B}(3.67)$ \\
$>50 \mathrm{~cm}$ & 49.3 & 61.1 & $55.2 \mathrm{C}(3.67)$ \\
Mean & $100.2 \mathrm{~b}(0.83)$ & $117.2 \mathrm{a}(0.70)$ & \\
\hline
\end{tabular}

Means followed by the same lower case letters in rows or upper case letters in columns are not different $(\mathrm{P}>0.05)$ - Tukey.

Values in parentheses refer to the standard error.

smallest values recorded for the $50 \mathrm{~cm}$ stratum, regardless the grazing treatment.

The potentially grazed strata (those containing herbage mass above the target post-grazing height) showed herbage bulk density values 42 and $62 \%$ lower than the lower strata (below 50 and $25 \mathrm{~cm}$ for $95 / 50$ and 95/25, respectively). The lower herbage bulk density on the upper strata of the swards is a consequence of leaves being the main predominant morphological component in the herbage mass (Table 3 ).

There was a grazing treatment $\times$ grazing cycle interaction $(\mathrm{P}<0.05)$, with herbage bulk density maintained relatively constant for $95 / 25$, but increasing from the first to the last grazing cycle for $95 / 50$, a likely consequence of the increased accumulation of stem and dead material under these circumstances, particularly towards the end of the experimental period (Figure 6). However, in the potentially grazed stratum (above the post-grazing height of $50 \mathrm{~cm}$ ) that behavior pattern was not observed, demonstrating that successive grazing cycles affected only the morphological composition of the herbage mass below the target postgrazing height.

The results from the chemical composition analyses on the morphological components of the pre-grazing sward herbage mass revealed that contents of crude protein (CP) in leaves $(\mathrm{P}=0.8861)$, stems $(\mathrm{P}=0.1941)$ and dead material $(\mathrm{P}=0.3036)$ were not affected by grazing treatment $\times$ vertical strata $\times$ grazing cycle interactions. Furthermore, the leaf CP content was not affected by the grazing treatment $\times$ vertical strata interaction ( $\mathrm{P}=0.0577)$, although there was a difference in the leaf CP content between vertical strata of the sward $(\mathrm{P}=0.0252)$ (Table 6).

In general, the upper stratum $(>50 \mathrm{~cm}$ ) had higher $\mathrm{CP}$ content than the intermediate $(25-50 \mathrm{~cm})$ and lower (0-25 cm) strata, certainly a consequence of the higher percentage of young and green tissue, with smaller percentage of cell wall constituents. Leaf blade from the
Table 6 - Content of crude protein (\%) in the morphological components of the pre-grazing herbage mass in Tanzania guineagrass subjected to rotational stocking managements according to sward strata

\begin{tabular}{lrrc}
\hline Strata & \multicolumn{1}{c}{ Leaf } & Stem & Dead material \\
\hline $95 / 25$ & & & \\
$0-25 \mathrm{~cm}$ & $9.3 \mathrm{c}(0.06)$ & $4.4 \mathrm{c}(0.13)$ & $5.2 \mathrm{a}(0.07)$ \\
$26-50 \mathrm{~cm}$ & $10.2 \mathrm{~b}(0.06)$ & $5.8 \mathrm{~b}(0.14)$ & $6.2 \mathrm{a}(0.08)$ \\
$>50 \mathrm{~cm}$ & $12.3 \mathrm{a}(0.06)$ & $10.2 \mathrm{a}(0.46)$ & - \\
\hline $95 / 50$ & & & \\
$0-25 \mathrm{~cm}$ & $9.0 \mathrm{c}(0.05)$ & $4.4 \mathrm{c}(0.11)$ & $5.7 \mathrm{a}(0.06)$ \\
$26-50 \mathrm{~cm}$ & $9.6 \mathrm{~b}(0.05)$ & $5.1 \mathrm{~b}(0.11)$ & $5.4 \mathrm{a}(0.06)$ \\
$>50 \mathrm{~cm}$ & $12.3 \mathrm{a}(0.05)$ & $6.7 \mathrm{~b}(0.29)$ & - \\
\hline
\end{tabular}

Means followed by the same lower case letters in rows are not differen $(\mathrm{P}>0.05)$ - Tukey.

Values in parentheses refer to the standard error.

lower stratum $(0-25 \mathrm{~cm})$ showed lower CP concentration, since they were older leaves and presented a larger percentage of $\mathrm{N}$ linked to indigestible constituents of the plant tissue.

There was a grazing treatment $\times$ vertical strata interaction for $\mathrm{CP}$ content of the stems $(\mathrm{P}=0.0486)$. Swards grazed to a post-grazing residue of $25 \mathrm{~cm}$ had higher $\mathrm{CP}$ concentration in stems positioned on the upper stratum (>50 cm) than swards grazed to $50 \mathrm{~cm}$, certainly a result of greater removal of stem tissue under more intense grazing conditions, favoring the accumulation of new tissue during regrowth with higher nutritive value (Cecato et al., 1985). On swards grazed to $50 \mathrm{~cm}$ post-grazing residue, the $\mathrm{CP}$ content of stems at the upper stratum was similar to that of the $25-50 \mathrm{~cm}$ stratum, with the lowest values recorded for the lowest stratum $(0-25 \mathrm{~cm})$.

The CP content of the dead material in the pre-grazing herbage mass remained unchanged with either grazing treatments or vertical strata of the sward $(\mathrm{P}>0.05)$. Overall, the leaf blade had higher CP content than stems and dead material (4.3 and 4.8 units, respectively).

There was no grazing treatment $\times$ grazing cycle and grazing cycle $\times$ vertical strata interaction on the content of neutral detergent fiber (NDF) and acid detergent lignin (ADL) as well as on the "in vitro" organic matter digestibility (IVOMD) of the leaf blade, stems and dead material for individual treatments $(\mathrm{P}>0.05)$. These variables remained unchanged with the grazing treatments $(\mathrm{P}>0.05)$, but were influenced by the vertical strata of the sward $(\mathrm{P}<0.0001$; Table 7).

For leaf blade, the NDF content was lower in the upper strata $(>50 \mathrm{~cm})$, with similar values recorded for the intermediate $(25-50 \mathrm{~cm})$ and lower $(0-25 \mathrm{~cm})$ strata. 
Table 7 - Contents of neutral detergent fiber (NDF) and acid detergent lignin (ADL), and “in vitro" organic matter digestibility (IVOMD) of the morphological components in the pre-grazing herbage mass of Tanzania guineagrass subjected to rotational stocking managements according to sward vertical strata

\begin{tabular}{lccc}
\hline Strata & Leaf & Stem & Dead material \\
\hline NDF (\%) & & & \\
$0-25 \mathrm{~cm}$ & $76.6 \mathrm{ab}(0.15)$ & $79.9 \mathrm{a}(0.54)$ & $79.0 \mathrm{a}(0.40)$ \\
$26-50 \mathrm{~cm}$ & $77.6 \mathrm{a}(0.15)$ & $79.7 \mathrm{a}(0.59)$ & $78.0 \mathrm{a}(0.42)$ \\
$>50 \mathrm{~cm}$ & $75.7 \mathrm{~b}(0.15)$ & $76.8 \mathrm{a}(1.71)$ & - \\
\hline ADL $(\%)$ & & & \\
$0-25 \mathrm{~cm}$ & $3.7 \mathrm{a}(0.01)$ & $4.9 \mathrm{a}(0.02)$ & $5.9 \mathrm{a}(0.12)$ \\
$26-50 \mathrm{~cm}$ & $3.4 \mathrm{~b}(0.01)$ & $4.6 \mathrm{~b}(0.02)$ & $5.0 \mathrm{~b}(0.12)$ \\
$>50 \mathrm{~cm}$ & $2.9 \mathrm{c}(0.01)$ & $4.0 \mathrm{c}(0.05)$ & - \\
\hline IVOMD $\%)$ & & & \\
$0-25 \mathrm{~cm}$ & $54.7 \mathrm{~b}(0.48)$ & $47.3 \mathrm{c}(0.09)$ & $27.2 \mathrm{~b}(1.17)$ \\
$26-50 \mathrm{~cm}$ & $56.4 \mathrm{~b}(0.48)$ & $51.9 \mathrm{~b}(0.10)$ & $36.9 \mathrm{a}(1.21)$ \\
$>50 \mathrm{~cm}$ & $60.5 \mathrm{a}(0.48)$ & $57.8 \mathrm{a}(0.29)$ & - \\
\hline
\end{tabular}

Means followed by the same lower case letters in columns are not different (P>0.05) - Tukey.

Values in parentheses refer to the standard error.

This is a result of the variation in the structure along the vertical profile of the sward, characterized by a higher percentage of old, mature leaves, stems and dead material close to the ground level in relation to the top of the sward (Table 3). In the upper stratum, the IVOMD of leaf blade and stems was higher than in the lower strata. For dead material, the same IVOMD variation pattern with the vertical strata was observed, with the difference that there was no dead material positioned in the upper stratum $(>50 \mathrm{~cm}$ ). This indicates a higher nutritive value of herbage on the upper strata of the swards, suggesting that these should be grazed preferably by high performance/ nutritional requirement animals (Hodgson, 1990). The ADL content decreased from the lower to the upper strata of the sward, and certainly was a consequence of the variation in the distribution of morphological components and maturity of plant tissues along the vertical strata of the sward (Table 3).

The content of CP, NDF and ADL as well as IVOMD (Table 8) varied with the grazing treatments $(\mathrm{P}<0.05)$. Swards grazed to $50 \mathrm{~cm}$ post-grazing residue had higher $\mathrm{CP}$ and IVOMD contents than those grazed at $25 \mathrm{~cm}$, a likely consequence of the higher percentage of leaf tissue remaining in the post-grazing herbage mass (32 and $11 \%$ of leaf for the post-grazing residues of 50 and $25 \mathrm{~cm}$, respectively). On the other hand, the NDF and ADL contents of were higher for swards grazed to $25 \mathrm{~cm}$ in relation to those
Table 8 - Least square means for the contents of crude protein (CP), neutral detergent fiber (NDF) and acid detergent lignin (ADL), and “in vitro” organic matter digestibility (IVOMD) of the post-grazing herbage mass of Tanzania guineagrass subjected to rotational stocking managements

\begin{tabular}{lrr}
\hline Variable & \multicolumn{2}{c}{ Treatment } \\
\cline { 2 - 3 } & \multicolumn{1}{c}{$95 / 25$} & \multicolumn{1}{c}{$95 / 50$} \\
\hline CP (\%) & $5.4 \mathrm{~b}(0.74)$ & $6.7 \mathrm{a}(0.64)$ \\
NDF (\%) & $80.1 \mathrm{a}(0.18)$ & $79.0 \mathrm{~b}(0.15)$ \\
ADL (\%) & $5.4 \mathrm{a}(0.02)$ & $5.0 \mathrm{~b}(0.02)$ \\
IVOMD (\%) & $36.6 \mathrm{~b}(2.13)$ & $42.0 \mathrm{a}(1.82)$ \\
\hline
\end{tabular}

Means followed by the same lower case letters in rows are not different $(\mathrm{P}>0.05)$ - Tukey.

Values in parentheses refer to the standard error.

grazed at $50 \mathrm{~cm}$, consequence of the higher percentage of dead material in the post-grazing herbage mass under these circumstances (58 and 38\% for the post-grazing residues of 25 and $50 \mathrm{~cm}$, respectively), since the percentage of stems remained unchanged with the grazing treatments.

\section{Conclusions}

The rotational management of Tanzania guineagrass should be characterized by a pre-grazing condition around 65-70 cm pre-grazing sward height, regardless the targets of post-grazing residue used. The definition of post-grazing sward height $(25$ or $50 \mathrm{~cm}$ ) is a function of the objective and type of animal being used in the system. A low post-grazing residue would ensure high grazing efficiency, but lower nutritive value of the herbage in the grazing horizon of the swards. On the other hand, a high post-grazing residue would ensure higher nutritive value of the herbage in the grazing horizon, but low grazing efficiency.

\section{Acknowledgements}

The authors would like to thank the Universidade Federal de Viçosa, Embrapa Gado de Corte, Fundação de Apoio ao Desenvolvimento do Ensino, Ciência e Tecnologia do Estado de Mato Grosso do Sul (FUNDECT), Conselho Nacional de Desenvolvimento Científico e Tecnológico (CNPq) for overall support.

\section{Literature Cited}

BARBOSA, R.A.; NASCIMENTO JR., D.; EUCLIDES, V.P.B. et al. Capim-tanzânia submetido a combinações entre intensidade e freqüência de pastejo. Pesquisa Agropecuária Brasileira, v.42, n.3, p.329-340, 2007. 
BRÂNCIO, P.A.; NASCIMENTO JR., D.; EUCLIDES, V.P.B. et al. Avaliação de três cultivares de Panicum maximum Jacq. sob pastejo: composição química e digestibilidade da forragem. Revista Brasileira de Zootecnia, v.31, n.4, p.1605-1613, 2002.

BRÂNCIO, P.A.; NASCIMENTO JR., D.; EUCLIDES, V.P.B. et al. Avaliação de três cultivares de Panicum maximum Jacq. sob pastejo: composição da dieta, consumo de matéria seca e ganho de peso animal. Revista Brasileira de Zootecnia, v.32, n.5, p.1037-1044, 2003.

CARNEVALLI, R.A.; DA SILVA, S.C.; BUENO, A.A.O. et al. Herbage production and grazing losses in Panicum maximum cv. Mombaça under four grazing managements. Tropical Grasslands, v.40, p.165-176, 2006.

CECATO, U.; SANTOS, G.L.; BARRETO, I.L. Efeito de doses de nitrogênio e alturas de cortes sobre a produção, qualidade e reservas de glicídios de Setaria anceps Stapf. cv Kazungula. Ciência Rural, v.15, n.4, p.367-378, 1985.

DA SILVA, S.C. Understanding the dynamics of herbage accumulation in tropical grass species: the basis for planning efficient grazing management practices. In: INTERNATIONAL SYMPOSIUM ON GRASSLAND ECOPHYSIOLOGY AND GRAZING ECOlOGY, 2., 2004, Curitiba. Proceedings... Curitiba: 2004. (CD-ROM).

DA SILVA, S.C.; CARVALHO, P.C.F. Foraging behaviour and intake in the favourable tropics/sub-tropics. In: McGILLOWAY, D.A. (Ed.) Grassland: a global resource. Wageningen: Wageningen Academic Publishers, 2005. p.81-95.

EMPRESA BRASILEIRA DE PESQUISA E AGROPECUÁRIA EMBRAPA - Centro Nacional de Pesquisa de Solos. Manual de métodos de análise química do solo. 2.ed. Brasília: 1997. 212p.

HODGSON, J.; DA SILVA, S.C. Options in tropical pasture management. In: REUNIÃO ANUAL DA SOCIEDADE BRASILEIRA DE ZOOTECNIA, 39.; SIMPÓSIO INTERNACIONAL DE FORRAGICUlTURA, 2002, Recife. Anais... Recife: Sociedade Brasileira de Zootecnia, 2002. p.180-202.

HODGSON, J. Grazing management: science into practice. New York: John Wiley \& Sons, 1990. 203p.

IUSS Working Group WRB. [2006]. World reference base for soil resources 2006: World Soil Resources Reports n. 103. FAO, Rome. Disponível em: <http://www.fao.org/ag/Agl/agll/ wrb/doc/wrb2006final.pdf> Acesso em: 20/8/2007.

MERTEN, G.C.; SHENK, J.S.; BARTON, F.E. Near infrared reflectance spectroscopy (NIRS), analysis of forage quality. Washington: USDA, ARS, 1985. 110p. (Agriculture Handbook, 643).

NASCIMENTO JR., D.; DA SILVA, S.C.; ADESE, B. Perspectivas futuras do uso de gramíneas em pastejo. In: REUNIÃO ANUAL DA SOCIEDADE BRASILEIRA DE ZOOTECNIA, 31, 2004, Campo Grande. Anais... Campo Grande: Sociedade Brasileira de Zootecnia, 2004. p.130-141.

PEDREIRA, J.V.S.; MATTOS, H.B. Crescimento estacional de vinte e cinco espécies de variedades de capins. Boletim de Indústria Animal, v.38, n.2, p.117-143, 1981.

SBRISSIA, A.F.; DA SILVA, S.C. O ecossistema de pastagens e a produção animal In: REUNIÃO ANUAL DA SOCIEDADE BRASILEIRA DE ZOOTECNIA, 38., 2001, Piracicaba. Anais... Piracicaba: Sociedade Brasileira de Zootecnia, 2001. p.731-754 